\title{
Keefektifan SMP Negeri Standar Nasional di Kota Semarang (Pengaruh Kesehatan Sekolah, Sumber Daya Manusia, Sarana- prasarana, Peranserta Masyarakat Terhadap Prestasi Akademik)
}

\author{
Kasmadi Imam Supardi \\ FMIPA Universitas Negeri Semarang
}

\begin{abstract}
Abstrak: Tujuan penelitian ialah untuk menentukan besaran pengaruh kesehatan sekolah, sumber daya manusia, sarana-prasarana, dan peran serta masyarakat terhadap prestasi akademik SMP Negeri Standar Nasional. Anggota populasi sekaligus sampel penelitian adalah lima belas SMP Negeri Standar Nasional di kota Semarang. Keefektifan sekolah diungkap dari persepsi guru SMP Negeri Standar Nasional di Kota Semarang dengan kuesioner. Analisis data dilakukan dengan teknik confirmatory factor analysis second order dari program statistik LISREL linear structure relationship. Hasil penelitian menunjukkan bahwa pengaruh sumber daya manusia, sarana-prasarana, peran serta masyarakat, dan kesehatan sekolah secara bersama-sama terhadap prestasi akademik sebesar 93,70\%. Prestasi akademik rata-rata nilai ujian nasional siswa SMP Negeri Standar Nasional dalam kategori baik, termasuk mata pelajaran Matematika dan IPA.
\end{abstract}

Kata kunci: keefektifan sekolah, sekolah standar nasional (SSN), kesehatan sekolah, sarana-prasarana prestasi akademik, dan peran serta masyarakat

\begin{abstract}
The goal of the research is to determine value of influence of perception health school, education staff, media of learning, and publics services to academic prestation of students. The members of population and sample are fiveteen the National Standar of SMP in Semarang city. Effectiveness school be shown by perception respondent of teachers in Semarang city with quesionare. The data analysis use confirmatory factor analysis second order from statistics programe LISREL linear structure relationship. The result of reseach is like below. The total influence of education staff, media of learning, and publics services, and health of school to academic prestation of students is $93,70 \%$. The academic prestation of national test for student of SMP Negeri Standar Nasional is good, included the lesson of Mathematics and Sciences.
\end{abstract}

Key words: effectiveness school, national standard school, education staff, media of learning, publics services, health of school and academic prestation

\section{Latar Belakang}

Masyarakat menganggap kualitas pembelajaran di Sekolah Standar Nasional yang termasuk kategori sekolah unggulan lebih baik dari jenis sekolah potensial dan sekolah rintisan, sehingga mempunyai potensi besar menjadi sekolah efektif (Mohrman, 1994: 81). Keefektifan sekolah tidak ditentukan oleh sebutan yang telah diberikan oleh pemerintah maupun masyarakat, tetapi ditentukan oleh seberapa besar tujuan sekolah yang telah direncanakan dapat dicapai. Keefektifan sekolah bisa dicapai oleh kategori sekolah unggulan maupun sekolah lainnya, tandanya ialah prestasi akademik siswanya tinggi (Finn. 1984: 24) dan (Prasch. 1984: 27). Keefektifan sekolah adalah derajat dimana organisasi sekolah mencapai tujuannya (Etzioni 1964: 187) dan diukur dari tingkat kinerja sekolah (Komariyah 2006:7). Sekolah efektif dapat terjadi pada sekolah yang masukan siswanya biasa-biasa saja atau kurang baik, tetapi diproses di tempat yang baik dengan cara yang baik pula sehingga keluarannya bagus (Suyanto 2002:5), sesuai dengan gagasan Mortimore: one in which students progress further than might be expected from a consideration of intake (Mortimore, 1993: 9).

Di kota Semarang pada tahun 2009 memiliki 40 SMP Negeri dengan 15 berkategori SSN dan 2 berkategori RSBI, sementara 23 SMP Negeri lainnya nonSBI nonSSN termasuk sekolah 
potensial atau sekolah rintisan. Apakah ke-15 SMP Negeri SSN di kota Semarang memenuhi harapan masyarakat sebagai sekolah efektif, dengan merumuskan lebih dahulu parameter keefektifan sekolah berdasarkan teori keefektifan organisasi, dan teori keefektifan sekolah. Di antara teori-teori keefektifan sekolah, parameter penting yang digunakan untuk menentukan keefektifan sekolah ialah prestasi akademik (Finn 1984:24) dan (Prasch 1984:27).

Berdasarkan teori tersebut, parameter keefektifan sekolah ditinjau dari faktor-faktor yang menentukannya, yakni: kesehatan sekolah, SDM, sarana-prasarana, dan peran serta masyarakat sebagai variabel eksogen, serta prestasi akademik sebagai variabel endogen. Rumusan parameter ini selanjutnya digunakan untuk mengukur keefektifan sekolah. Berdasarkan parameter tersebut, penelitian dilakukan untuk mengetahui seberapa besar variabel kesehatan sekolah, sumber daya manusia, saranaprasarana, dan peran serta masyarakat berpengaruh terhadap prestasi akademik. Masalah utama penelitian ialah berapa besaran pengaruh sumber daya manusia, sarana prasarana, peran serta masyarakat, dan kesehatan sekolah terhadap prestasi akademik (SMP Standar Nasional Negeri) di kota Semarang yang merepresentasikan keefektifan sekolah? Masalah utama tersebut disederhanakan menjadi: Berapa besaran sumber daya manusia, sarana-prasarana, peranserta masyarakat, dan kesehatan sekolah masing-masing dan bersamasama mempengaruhi prestasi akademik?

Tujuan penelitian ialah untuk menentukan besaran sumber daya manusia, saranaprasarana, peran serta masyarakat, dan kesehatan sekolah masing-masing dan bersamasama mempengaruhi prestasi akademik.

\section{Kajian Literatur}

\section{Sekolah Standar Nasional}

Pasal 35 Undang-Undang Nomor 20 Tahun 2003 tentang Sistem Pendidikan Nasional mengamanatkan bahwa Standar Nasional Pendidikan (SNP) dijadikan pedoman pengembangan satuan pendidikan. SNP tersebut dimaksudkan sebagai acuan pengembangan dan pengendalian pendidikan, antara lain pengembangan kurikulum, kompetensi lulusan, penilaian, proses pembelajaran, tenaga kependidikan, sarana dan prasaranan, pengelolaan pembiayaan, dan penilaian pendidikan. Undang-undang Nomor 20 Tahun 2003 juga menyebutkan standar nasional pendidikan mencakup standar isi, proses, kompetensi lulusan, tenaga kependidikan, saranaprasarana, pengelolaan, pembiayaan, dan penilaian pendidikan. Hal ini juga lebih ditegaskan lagi dalam Peraturan Pemerintah Nomor 19 Tahun 2005 tentang Standar Nasional Pendidikan. Ketentuan tentang SNP berupa dokumen, yang menurut UU Nomor 20/2003 telah diwujudkan dalam Peraturan Pemerintah tersebut. Untuk memudahkan bagi sekolah maupun masyarakat pada umumnya dalam memahami bagaimana wujud sekolah yang telah memenuhi SNP diperlukan contoh nyata, berupa keberadaan Sekolah Standar Nasional. Dengan adanya Sekolah Standar Nasional, masyarakat dapat memperoleh gambaran nyata tentang Sekolah Standar Nasional, dan sekolah-sekolah kategori rintisan dan potensial disekitar SMP Standar Nasional bisa mengacu kepada SMP Standar Nasional tersebut.

\section{Keefektifan Sekolah}

Sekolah memiliki kebebasan mengambil keputusan mengelola organisasinya sendiri untuk mendapatkan keefektifan sekolah yang maksimal, di era otonomi daerah. Dengan keputusan memilih menjadi SMP Standar Nasional apakah SMP Negeri ini menjadi sekolah efektif. Jadi keefektifan sekolah ditentukan sendiri oleh sekolah (Nugroho 2007: 1).

Keefektifan sekolah adalah tingkatan kualitas dan kesetaraan sekolah berhasil mencapai tujuan yang telah ditetapkannya (Lauglin 2006:1) berdasarkan tuntutan konstituen strategisnya. Semakin besar tujuan sekolah tercapai semakin besar keefektifan sekolah tersebut. Paradigma penelitian menggunakan teori Murphy dan Beck, teori Finn dan Prasch yang sejalan dengan arah dan tujuan MBS, yang menyatakan bahwa faktorfaktor yang mempengaruhi keefektifan sekolah ialah: 1) manajemen yang baik atau kesehatan sekolah (Salis 2006: 73); 2) tersedianya sumber daya manusia (Zamroni 2000: 56); 3) tersedianya sumber dana (Psacharoupoulus 1987: 3), sarana 
dan prasarana (Supriadi 2005: 30); 4) prestasi akademik yang tinggi (Beck dan Murphy 1996: 36); dan 5) peran serta masyarakat (Depdikbud. 1998: 76). Kelima faktor tersebut merupakan variabel eksogen dalam penelitian ini dan dijabarkan ke dalam variabel pengukuran-variabel pengukuran. Faktor-faktor dalam paradigma penelitian ini digambarkan pada Gambar 1.

\section{Kesehatan Sekolah}

Peter Senge (1990: 7-23) salah satu pelopor teori pembelajaran (learning organization theory) menyatakan bahwa organisasi sebagai satu kesatuan sistem dan bukan secara individu. Teori ini menyatakan perlunya interaksi positif antar pelaku dalam organisasi sebagai satu kesatuan (bukan secara individu) untuk belajar terus menerus meningkatkan kapasitasnya dan meningkatkan kinerja organisasi serta mencapai tujuan organisasi secara maksimal. Menurut teori ini SDM (guru) juga karyawan non guru sebagai unsur organisasi perlu belajar terus menerus untuk meningkatkan kapasitasnya sehingga kinerja organisasi meningkat.
Sejalan dengan pendapat Peter Senge adalah Michael Beck yang mendefinisikan learning organization sebagai sebuah organisasi yang memfasilitasi pembelajaran dan pengembangan personal bagi seluruh staf, sambil secara terus menerus melakukan perubahan (peningkatan kapasitas) terhadap diri sendiri. Pakar lain yang juga sejalan dengan Peter Senge adalah Karen Watkins dan Victoria Matsick yang melihat sebuah kekuatan kunci (key strength) dari learning organization karena kapasitas organisasi yang mendukung perubahan atau proses transformasi. Mereka menyatakan bahwa:

"The learning organization empower its people, integrates quality initiatives with quality of work life, creates free space for learning, encourages collaboration and sharing the gains, promotes inquiry, and create continuous learning opportunities" Marquardt (1994: 20-21)

Apa yang dikemukakan oleh Peter Senge, Michael Beck, Watkins dan Matsick merupakan suatu pembaharuan dalam teori organisasi yang mengarah pada dinamisme dan perkembangan organisasi melalui proses pembelajaran seluruh

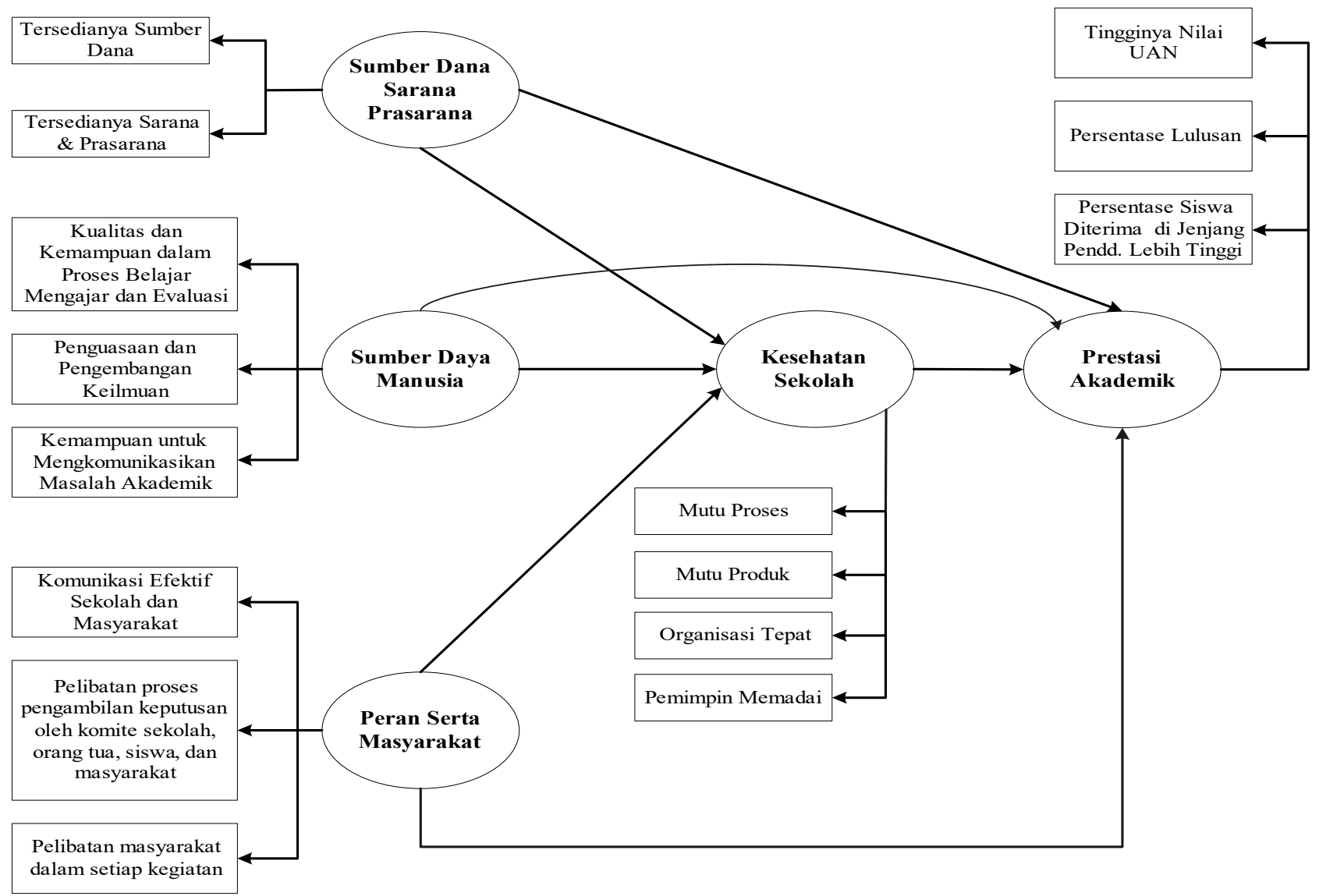

Gambar 1. Faktor-faktor Keefektifan Sekolah 
anggota organisasi yang berkesinambungan untuk meningkatkan kapasitas dan kinerja dalam rangka mencapai tujuan organisasi. Pandangan teori learning organization yang mengedepankan adanya proses pembelajaran dan peningkatan kapasitas sumberdaya manusia merupakan ciri penting organisasi yang dinamis. Oleh karena itu, para pelaku implementasi kebijakan publik bidang pendidikan sudah seyogyanya mempertimbangkan teori learning organization dalam mengimplementasikan kebijakan publik.

\section{Sumber daya Manusia, Sarana-prasarana, dan Peran serta Masyarakat}

Sumber daya manusia pelaku pendidikan yang utama adalah guru disamping tenaga kependidikan lainnya, seperti: tata usaha, tenaga laboratorium, pustakawan, dan tenaga teknis. Sebagai pelaku utama pendidikan di sekolah, guru profesional merupakan kebutuhan pokok pada sekolah efektif.

Sarana-prasarana pendidikan pada hakekatnya merupakan fasilitas pendidikan yang dapat mempermudah proses pembelajaran untuk mencapai tujuan yang telah ditetapkan. Oleh karena itu, sarana-prasarana yang memadai dan sesuai dengan tingkat mempengaruhi akan mendukung kualitas proses dan hasil pembelajaran, sehingga keefektifan sekolah juga meningkat. Salah satu tujuan pembelajaran adalah tercapainya kompetensi berfikir, bersikap dan berperilaku ilmiah tertentu sesuai dengan bidang ilmu yang dipelajari.

Sarana-prasarana pendidikan pada hakekatnya merupakan fasilitas pendidikan yang dapat mempermudah proses pembelajaran untuk mencapai tujuan yang telah ditetapkan. Oleh karena itu, sarana-prasarana yang memadai dan sesuai dengan tingkat mempengaruhi akan mendukung kualitas proses dan hasil pembelajaran, sehingga keefektifan sekolah juga meningkat (Supriadi. 2005: 23). Salah satu tujuan pembelajaran adalah tercapainya kompetensi berfikir, bersikap dan berperilaku ilmiah tertentu sesuai dengan bidang ilmu yang dipelajari.

Hubungan sekolah dengan masyarakat di sekitarnya sangat penting. Di satu sisi, sekolah memerlukan masukan dari masyarakat dalam menyususn program yang relevan, skaligus memerlukan dukungan masyarakat dalam melaksanakan program tersebut. Di pihak lain, masyarakat memerlukan jasa sekolah untuk mendapatkan program-program pendidikan sesuai dengan yang diinginkan. Jalinan semacam ini dapat terjadi, jika pihak sekolah aktif dan dapat membangun hubungan dengan masyarakat yang saling menguntungkan, demi anak didik. Jadi, prinsip menumbuhkan hubungan dengan masyarakat adalah dapat saling memberikan kepuasan. Salah satu jalan penting untuk membina hubungan dengan masyarakat adalah menetapkan komunikasi yang efektif, Depdikbud (1998: 150).

\section{Penelitian Terdahulu}

Beberapa penelitian tentang keefektifan sekolah telah dilaksanakan oleh peneliti terdahulu. Variabel dari beberapa penelitian terdahulu dapat digunakan untuk membentuk konstruk (hubungan struktural antar variabel) dalam penelitian ini. Penelitian ini berbeda dari penelitian-penelitian keefektifan organisasi sekolah yang telah dilakukan oleh peneliti terdahulu. Beberapa penelitian terdahulu yang mendukung terbentuknya konstruk dalam penelitian ini sebagai berikut.

Brookover meneliti pada sampel random dari 2.226 sekolah dasar di Michigan. Variabel dependennya adalah keefektifan, yang diukur adalah skor rata-rata prestasi siswa kelas empat dengan menggunakan standar Michigan Assesment Program, sedangkan variabel bebas yang menjadi kunci adalah iklim sekolah. Iklim sekolah meliputi gabungan variabel-variabel yang didefinisikan oleh anggota kelompok. Variabel iklim yang mendasar diukur dari harapan-harapan di sekolah, atau lebih cocok disebut dengan Student Sense of Akademik Utility. Variabel bebas yang utama dalam penelitian itu adalah: (1) rata-rata Status Ekonomi Sosial (SES) tingkat sekolah; (2) komposisi ras di sekolah; (3) iklim di sekolah. Hasilnya menyatakan bahwa beberapa aspek dari lingkungan sosial sekolah secara jelas membuat sesuatu perbedaan dalam prestasi akademik sekolah. Walaupun mereka mempunyai perbedaan yang besar antara tingkat prestasi dalam berbagai sekolah, sosial ekonomi, dan komposisi ras dari siswa dalam sekolah tersebut, tetapi 
terhitung persentase variannya kecil. Variabel yang kritis adalah kuatnya asosiasi dengan ukuran obyektif dari prestasi siswa adalah iklim sosial dari sekolah. Hasil penelitian ini dapat digunakan untuk membentuk hubungan struktural variabel kesehatan sekolah dengan prestasi akademik dalam penelitian ini (Owens 1995: 94-95)

Dharma (2005: 32) dalam disertasinya yang berjudul School Effetiveness and Academic Achievements, An Empirical Evidence From American Public Schools memberi sumbangan terbentuknya hubungan struktural kesehatan sekolah, sumber daya manusia, sarana-prasarana dan peran serta masyarakat terhadap prestasi akademik dalam penelitian ini. Disertasi itu menguji hubungan antara karakteristik-karakteristik siswa, pengalaman sebelum masuk sekolah, sumber daya sekolah, variabel-variabel proses sekolah dan prestasi akademik siswa kelas lima di sekolah dasar negeri. Penelitian tersebut telah menguji kontribusi relatif dari berbagai variabel input terhadap variabel dependen output sebagai wakil dari kualitas pendidikan. Penelitian dilakukan terhadap prestasi siswa dalam membaca dan matematika. Secara umum hasil penelitian mengindikasikan bahwa latar belakang keluarga mempunyai pengaruh yang kuat terhadap prestasi siswa baik dalam mata pelajaran membaca maupun matematika. Prestasi siswa pada kelompok SES rendah nampak lebih rendah dibanding dengan siswa pada kelompok SES tinggi. Komposisi ras mempunyai pengaruh yang kuat terhadap performan siswa antar sekolah. Pengalaman sebelum masuk sekolah secara signifikan menghubungkan dengan prestasi siswa dalam model seluruh sekolah dan di dalam kelompok SES rendah. Karakteristik-karakteristik proses diindikasikan oleh keterlibatan orang tua dan memaksimalkan waktu belajar secara signifikan memprediksi performan siswa pada kedua mata pelajaran tersebut. Keterlibatan orang tua dijelaskan dengan varian terbesar dari prestasi membaca rata-rata sekolah pada kelompok SES rendah. Secara keseluruhan proses sekolah nampak membuat suatu perbedaan pada prestasi siswa kelas lima sesudah pengawasan pada latar belakang keluarga siswa.

Standfield, (1987) selama 20 bulan di Sekolah Dasar Garvin Missouri dan Gibbon di sekolah- sekolah negeri di Ohio selama tahun ajaran 1982/ 1983, keduanya menemukan bahwa peran kepala sekolah yang efektif dan profesional mampu mengangkat nama sekolah mereka sehingga mampu memperbaiki prestasi akademik mereka. Jadi kesehatan sekolah dan sumber daya manusia merupakan variabel yang sangat penting dalam meningkatkan prestasi akademik ( $w w w$. schoolparents.cambera.net.au/effective_schools)

Kali ini penelitian yang dilakukan berbeda dengan penelitian-penelitian terdahulu. Penelitian ini mengkaji keefektifan sekolah menengah pertama negeri yang berkategori sekolah standar nasional sebagai organisasi dan dikenal masyarakat sebagai sekolah unggulan. Keefektifan sekolah ditandai dengan prestasi akademik sebagai variabel endogen, sementara variabel eksogennya ialah: kesehatan sekolah, sumber daya manusia, sarana-prasarana, dan peran serta masyarakat. Penelitian ini mencari jawaban secara kualitatif dan kuantitatif pengaruh kesehatan sekolah, sumber daya manusia, sarana- prasarana, dan peran serta masyarakat terhadap prestasi akademik.

\section{Metodologi Penelitian Populasi dan Sampel Penelitian}

Populasi penelitian adalah 15 Sekolah Menengah Pertama Standar Nasional Negeri di Kota Semarang dengan pertimbangan bahwa penentuan status SMP Standar Nasional dilakukan oleh Pemerintah (Depdiknas) setelah sekolah memenuhi syarat formal. Subyek penelitian ini adalah guru. Guru diminta untuk menilai keefektifan sekolahnya sendiri. Menurut Sugiyono (2000: 66) sampel 210 guru (30\% populasi dengan tingkat kesalahan 5\%), diambil secara acak dari populasi 716 guru SMP Standar Nasional Negeri di kota Semarang. Persepsi guru terhadap sekolahnya merupakan indikator-indikator dari variabel eksogen dan variabel endogen yang menggambarkan keefektifan sekolahnya.

\section{Teknik Pengumpulan Data dan Instrumen Penelitian}

Teknik pengumpulan data dalam penelitian ini adalah dengan kuesioner. Instrumennya berbentuk kuesioner yang telah diuji validitas dan reliabilitasnya. Respondennya adalah 210 orang 
guru SMP sampel (Sugiyono 2000: 66) dari populasi 716 orang guru SMP Standar Nasional Negeri di Semarang. Instrumen yang telah memenuhi validitas dan reliabilitas digunakan untuk mengambil data.

\section{Hasil penelitian dan Pembahasan}

Hasil penelitian deskriptif adalah data mentah isian kuesioner yang telah diisi oleh 210 responden. Rata-rata persentase responden (guru) terhadap tiap-tiap variabel laten ditampilkan pada Tabel 1, sedang persentase tiaptiap variabel pengukuran sekolah ditampilkan pada Tabel 2.

Prestasi akademik rata-rata nilai ujian nasional empat mata pelajaran (Bahasa Indonesia, Bahasa Inggris, Matematika, dan IPA) tahun 2010 untuk SMP Negeri Standar Nasional dan Non Standar Nasional ditampilkan pada Tabel 3.

\section{Hasil Penelitian SEM dengan software LISREL Signifikansi Parameter}

Hasil perhitungan signifikansi parameter dari LISREL menyatakan bahwa: 1) variabel sumber daya manusia, sarana-prasarana, dan peran serta masyarakat mempengaruhi kesehatan sekolah dengan $\mathrm{R}^{2}=0,49 ; 2$ ) variabel kesehatan sekolah, sumber daya manusia, sarana-prasarana, peran serta masyarakat mempengaruhi prestasi akademik dengan $\mathrm{R}^{2}=0,48$.

\section{Uji Hipotesis}

Variabel-variabel penelitian yang telah disusun dalam hubungan struktural diuji kebenarannya dengan data model fit. Jika terdapat kesesuaian teori dan data, dilanjutkan dengan pengujian hipotesis.

Hipotesis yang diuji adalah: "Ada pengaruh sumber daya manusia, sarana-prasarana, dan peran serta masyarakat terhadap kesehatan

Tabel 1. Rata-rata persentase responden (guru) tiap-tiap variabel

\begin{tabular}{|l|l|l|l|}
\hline Variabel laten & Persen & Variabel laten & Persen \\
\hline Kesehatan sekolah & 72,68 & Prestasi akademik & 74,51 \\
\hline Sumberdaya manusia & 47,30 & Peransert Masyarakat & 62,38 \\
\hline Sarana-prasarana & 54,87 & & \\
\hline
\end{tabular}

Tabel 2. Persentase tiap-tiap Variabel Pengukuran

\begin{tabular}{|l|l|l|l|}
\hline Variabel pengukuran & Persen & Variabel pengukuran & Persen \\
\hline X1: mutu produk & 65,67 & X9: Tersedianya sarpras & 61,47 \\
\hline X2: mutu proses & 72,00 & Y1: tingginya nilai UAN & 63,87 \\
\hline X3: organisasi tepat & 76,13 & Y2: Persentase lulusan & 80,07 \\
\hline $\begin{array}{c}\text { X4: pemimpin } \\
\text { Memadai }\end{array}$ & 76,93 & $\begin{array}{c}\text { Y3: Persentase siswa } \\
\text { diterima pada jenjang } \\
\text { lebih tinggi }\end{array}$ & 79,60 \\
\hline $\begin{array}{c}\text { X5: kualitas dan } \\
\text { kemampuan dalam } \\
\text { PBM dan evaluasi }\end{array}$ & 67,53 & $\begin{array}{c}\text { X10: komunikasi efektif } \\
\text { sekolah }\end{array}$ & 61,57 \\
\hline $\begin{array}{c}\text { X6: penguasaan dan } \\
\text { pengembangan } \\
\text { keilmuan }\end{array}$ & 46,40 & $\begin{array}{c}\text { X11: pelibatan } \\
\text { pengambilan } \\
\text { keputusan oleh OT, } \\
\text { siswa, dan masyarakat }\end{array}$ & 57,00 \\
\hline $\begin{array}{c}\text { X7: kemampuan } \\
\text { mengkomunikasi } \\
\text { masalah akademik }\end{array}$ & 27,47 & X12: pelibatan masyarakat \\
dalam setiap kegiatan & 68,47 \\
\hline $\begin{array}{c}\text { X8: tersedianya sumber } \\
\text { dana }\end{array}$ & 48,27 & & \\
\hline
\end{tabular}


Tabel 3. Prestasi Akademik Rata-rata Nilai UN SMP Negeri Standar Nasional dan Non Standar Nasional di Kota Semarang Tahun 2010

\begin{tabular}{|l|l|l|l|l|l|}
\hline $\begin{array}{l}\text { Jenis } \\
\text { Sekolah }\end{array}$ & $\begin{array}{l}\text { Rata-rata } \\
\text { Nilai B. Ind }\end{array}$ & $\begin{array}{l}\text { Rata-rata } \\
\text { Nilai B. Ingg }\end{array}$ & $\begin{array}{l}\text { Rata-rata } \\
\text { Nilai Mat }\end{array}$ & $\begin{array}{l}\text { Rata-rata } \\
\text { Nilai IPA }\end{array}$ & $\begin{array}{l}\text { Rata-rata } \\
\text { JumlahNilai \% }\end{array}$ \\
\hline SMP SSN & 8,53 & 7,63 & 7,90 & 7,71 & $32,22=80,55 \%$ \\
\hline $\begin{array}{l}\text { SMP Non } \\
\text { SSN }\end{array}$ & 7,82 & 6,12 & 6,26 & 7,42 & $27,53=68,83 \%$ \\
\hline
\end{tabular}

sekolah" diterima. Persamaan strukturalnya lihat Tabel 4.

Berdasarkan skor-skor yang tersaji di dalam Tabel 4 dapat dijelaskan sebagai berikut: 1) Besar pengaruh sumber daya manusia terhadap kesehatan sekolah adalah sebesar $(0,32)^{2}$, yakni 0,1024 . Dengan demikian dapat diketahui bahwa $10,24 \%$ perubahan yang terjadi pada kesehatan sekolah secara langsung disebabkan adanya perubahan pada sumber daya manusia, 2) Besar pengaruh sarana-prasarana terhadap kesehatan sekolah adalah sebesar $(0,16)^{2}$, yakni 0,0256 . Dengan demikian dapat diketahui bahwa 2,56\% perubahan yang terjadi pada kesehatan sekolah adalah disebabkan oleh adanya perubahan pada sarana-prasarana; dan 3) Besar pengaruh variabel peran serta masyarakat terhadap kesehatan sekolah adalah sebesar $(0,10)^{2}$, yakni 0,010 . Dengan demikian dapat diketahui bahwa $1,00 \%$ perubahan yang terjadi pada kesehatan sekolah adalah disebabkan oleh adanya perubahan peran serta masyarakat. Hipotesis yang diuji adalah "Ada pengaruh sumber daya manusia, sarana-prasarana, dan peran serta masyarakat terhadap prestasi akademik" diterima.
Persamaan strukturalnya disajikan pada Tabel 5. Berdasarkan skor-skor yang tersaji di dalam Tabel 5 dapat dijelaskan sebagai berikut: 1) Besar pengaruh sumber daya manusia terhadap prestasi akademik adalah sebesar $(0,45)^{2}$, atau 0,2025. Dengan demikian, dapat diketahui bahwa 20,25\% perubahan yang terjadi pada prestasi akademik adalah disebabkan oleh adanya perubahan pada sumber daya manusia; 2) Besar pengaruh saranaprasarana secara langsung terhadap prestasi akademik adalah sebesar $(0,42)^{2}$, yakni 0,1764 . Dengan demikian dapat diketahui bahwa 17,64\% perubahan yang terjadi pada prestasi akademik secara langsung disebabkan adanya perubahan pada sarana-prasarana; dan 3) Besar pengaruh peran serta masyarakat secara langsung terhadap prestasi akademik adalah sebesar $(0,35)^{2}$, yakni 0,1225 . Dengan demikian dapat diketahui bahwa $12,25 \%$ perubahan yang terjadi pada prestasi akademik secara langsung disebabkan adanya perubahan pada peranserta masyarakat.

Hipotesis yang diuji adalah: "Ada pengaruh kesehatan sekolah terhadap prestasi akademik" diterima. Persamaan strukturalnya lihat Tabel 6.

Tabel 4. Persamaan Struktural Hasil Analisis Pengaruh Sumber Daya Manusia, Sarana-prasarana, dan Peran Serta Masyaraka terhadap Kesehatan Sekolah

\begin{tabular}{|c|c|c|c|c|c|}
\hline Exogenous & $\begin{array}{c}\text { Endogenous } \\
\text { Counstruct }\end{array}$ & $\mathrm{t}$ & $\alpha 0,05$ & Total & Keterangan \\
\hline Construct & Kessek & 3 & 1.96 & $\frac{\text { Effect }}{0.32}$ & Sianifikan \\
\hline Sarpras & 0,16 & 4,42 & 1,96 & 0,16 & Siqnifikan \\
\hline Peranserta Masyarakat & 0,10 & 5,02 & 1,96 & 0,10 & Signifikan \\
\hline
\end{tabular}

Tabel 5. Persamaan Struktural Hasil Analisis Pengaruh Sumber daya Manusia, Sarana-prasarana, dan peran serta masyarakat terhadap prestasi akademik

\begin{tabular}{|c|c|c|c|c|c|c|}
\hline $\begin{array}{l}\text { Exogenous } \\
\text { Construct }\end{array}$ & $\begin{array}{c}\text { Endogenous } \\
\text { Counstruct } \\
\text { PresAkdm }\end{array}$ & $\mathrm{t}$ & $\begin{array}{c}\alpha \\
0,05\end{array}$ & $\begin{array}{c}\text { Indirect } \\
\text { Effects }\end{array}$ & Total Effect & Keterangan \\
\hline SDM & 0,45 & 3,89 & 1,96 & 0,16 & 0,51 & Signifikan \\
\hline Sarpras & 0,42 & 4,87 & 1,96 & 0,10 & 0,45 & Signifikan \\
\hline Peranserta Masy & 0,35 & 5,36 & 1,96 & 0,07 & 0,38 & Signifikan \\
\hline
\end{tabular}


Pengaruh kesehatan sekolah terhadap prestasi akademik adalah sebesar $(0,66)^{2}$, yakni 0,4356 . Dengan demikian dapat diketahui bahwa $43,56 \%$ perubahan yang terjadi pada prestasi akademik adalah disebabkan oleh adanya perubahan pada kesehatan sekolah.

\section{Hasil analisis uji hipotesis secara keseluruhan} adalah sebagai berikut.

Pengaruh sumber daya manusia, saranaprasarana, peran serta masyarakat, dan kesehatan sekolah secara bersama-sama terhadap prestasi akademik adalah sebesar $20,25 \%+17,64 \%+12,25 \%+43,25 \%=93,70 \%$

\section{Pembahasan}

\section{Keefektifan Sekolah}

Pembahasan keefektifan sekolah atas temuan penelitian yang dilakukan ialah: 1) membandingkan prestasi akademik rata-rata nilai ujian nasional SMP Negeri Stándar Nasional dengan SMP Non Standar Nasional. Pada Tabel 3 dituliskan prestasi akademik rata-rata nilai ujian nasional untuk mata pelajaran Bahasa Indonesia, Bahasa Inggris, Matematika, dan IPA, serta jumlah nilai semua mata pelajaran tahun 2010 SMP Negeri Standar Nasional di kota Semarang lebih baik dari SMP Negeri Non Standar Nasional. Perbandingan nilai ujian nasional semua mata pelajaran di SMP Negeri SSN dan SMP Negeri Non SSN tahun 2010 sebagai berikut: Bahasa Indonesia 8,53 dibanding 7,82; Bahasa Inggris 7,63 dibanding 6,12; Matematika 7,90 dibanding 6,26; dan IPA 7,71 dibanding 7,42. Berdasarkan skor nilai ujian nasional tahun 2010 ini dapat dikatakan bahwa prestasi akademik SMP Negeri Standar Nasional Negeri di kota Semarang lebih baik dari SMP Negeri Non Standar Nasional. Rata-rata persentase nilai ujian nasional SMP Negeri Standar Nasional adalah $80,55 \%$ (baik), sementara SMP Negeri Non Standar Nasional adalah 68,83\% (cukup). 2) membahas kesehatan sekolah, sumber daya manusia, sarana-prasarana, peran serta masyarakat terhadap prestasi akademik.

\section{Kesehatan Sekolah}

Secara deskriptif rata-rata persentase kesehatan sekolah adalah $72,68 \%$ (baik), dan pengaruhnya terhadap prestasi akademik sebesar 43,25\%. Creech (1996: 7) menyatakan bahwa produk adalah titik pusat untuk tujuan dan pencapaian organisasi. Dalam sistem persekolahan, lulusan merupakan titik pusat tujuan (Soegito 2006: 26). Indikator-indikator sebagai rujukan untuk peningkatan kesehatan sekolah adalah sangat baik dan baik.

\section{Sumber Daya Manusia}

Kualitas dan kemampuan guru dalam PBM dan evaluasi pada posisi cukup, sedang penguasaan dan pengembangan keilmuan para guru masih kurang, sementara kemampuannya mengkomunikasikan masalah akademik berada pada posisi sangat kurang. Keadaan ini terjadi karena para guru kurang mengikuti kegiatan profesional. Pada hal salah satu kompetensi yang harus dimiliki oleh guru dari tujuh kompetensi guru menurut SNP adalah kompetensi profesional. Oleh karena itu, kompetensi profesional guru harus ditingkatkan secara perlahan-lahan dari kurang menjadi cukup kemudian menjadi baik dan sangat baik.

Pada umumnya persepsi guru dalam penguasaan PBM, dan pengembangan evaluasi penampilan guru oleh teman sejawat (Zamroni. 2000: 56) adalah baik. Guru telah melaksanakan proses pembelajaran secara konvensional dengan sangat baik, tetapi pengembangan keilmuaan dan kemampuannya dalam mengkomunikasikan gagasannya yang diwujudkan dalam laporan penelitian, penyusunan artikel, mereviu buku dan menyusun laporan (portofolio) masih sangat kurang. Padahal lingkungan siswa selalu berubah. Lingkungan alam, teknologi, sosial-budaya, dan nilai-nilai masyarakat berubah sementara guru

Tabel 6. Persamaan Pengaruh Kesehatan Sekolah Terhadap Prestasi Akademik

\begin{tabular}{|c|c|c|c|c|}
\hline \multirow{2}{*}{$\begin{array}{c}\text { Exogenous } \\
\text { Construct }\end{array}$} & $\begin{array}{c}\text { Endogenous } \\
\text { Counstruct }\end{array}$ & $\mathrm{t}$ & 0,05 & Kesimpulan \\
\cline { 2 - 3 } & PresAkdm & & & \\
\hline Kessek & 0,66 & 5,36 & 1,96 & Signifikan \\
\hline
\end{tabular}


kurang dalam mengikuti perkembangan dan perubahan-perubahan tersebut, akibatnya sumber daya manusia guru secara keseluruhan berada pada kategori kurang.

\section{Sarana-Prasarana}

Menurut persepsi responden, persentase variabel pengukuran sarana-prasarana sekolah berada pada posisi cukup. Kecukupan sarana-prasarana pada sekolah menunjukkan kemampuan sekolah dalam mengadakan, memelihara dan memanfaatkan sarana-prasarana pendidikannya. Salah satu tujuan pembelajaran adalah tercapainya kompetensi berpikir, bersikap, dan berperilaku ilmiah tertentu sesuai dengan bidang ilmu yang dipelajari. Kompetensi ini hanya dapat dicapai melalui pengalaman belajar yang melibatkan proses yang memungkinkan siswa mengembangkan kemampuan berpikir, bersikap, dan berperilaku ilmiahnya. Proses pembelajaran yang demikian memerlukan sarana-prasarana pendidikan yang dapat mendukung upaya menumbuhkan kompetensi yang diinginkan (Supriadi, 2005:30).

\section{Prestasi akademik}

Secara deskriptif variabel prestasi akademik dinilai baik oleh responden, yakni: tingginya nilai UN, persentase lulusan, dan persentase siswa diterima pada jenjang yang lebih tinggi. Menurut persepsi responden, prestasi akademik dinilai baik. Hal ini menunjukkan terjadi proses pembelajaran yang baik di sekolah itu. Jika mutu pendidikan semata-mata hanya dilihat dari parameter prestasi akademik, maka SMP Negeri Standar Nasional di Semarang berada pada posisi tinggi. Namun, menilai mutu pendidikan yang hanya menggunakan parameter prestasi akademik saja, adalah penilaian yang kurang lengkap. Ukuran keberhasilan pendidikan bukan semata-mata karena para siswanya mencapai nilai UN yang tinggi. Nilai UN yang berhasil dicapai oleh para siswanya hanyalah bagian kecil dari ukuran keberhasilan. Penilaian terakhir menunjukkan bahwa Intetllectual Quotient IQ berperan 20\% menunjang kesuksesan seseorang, 80\%-nya justru Emotional Quotient EQ dan Spiritual Quotient SQ, yang menunjang keberhasilan seseorang, (Sidi, 2001: 21).
Hal menarik yang perlu diperhatikan ialah, dengan sumber daya manusia guru yang berada pada kategori kurang menurut responden, tetapi prestasi akademik yang diraih siswanya adalah baik, sehingga keefektifan sekolahnya juga baik. Namun demikian, kualitas guru harus selalu ditingkatkan tidak saja dalam kualitas dan kemampuannya dalam PBM dan evaluasi, tetapi juga kemampuannya dalam mengembangkan keilmuannya, dan kemampuannya dalam mengkomunikasikan masalah akademik. Dengan demikian guru tidak ketinggalan dengan perkembangan dan perubahan yang terjadi di lingkungannya, dan prestasi akademik yang dicapai siswanya bisa menjadi sangat baik.

\section{Peran Serta Masyarakat}

Menurut persepsi responden persentase peran serta masyarakat adalah cukup. Peran serta masyarakat nampak pada kesertaannya dalam rapat pleno komite sekolah dan memenuhi kewajibannya memberikan bantuan dana pada komite sekolah sesuai keputusan pleno. Tetapi sejak diberlakukannya program sekolah gratis tahun pelajaran 2008/2009 oleh pemerintah kota Semarang, rapat pleno komite tidak membuat keputusan besarnya sumbangan dana orang tua kepada komite sekolah. Sumbangan dana orang tua kepada komite sekolah sifatnya sukarela bukan kewajiban. Sementara sumbangan dana dari pihak lain non orang tua siswa hampir tidak ada. Jadi peran serta masyarakat terhadap pendidikan untuk sekolah di kota Semarang masih perlu ditingkatkan lagi, karena menurut Undangundang Nomer 20 Tahun 2003 tentang Sistem Pendidikan Nasional pembiayaan pendidikan menjadi tanggung jawab bersama, pemerintah, orang tua dan masyarakat.

\section{Pembahasan Hubungan Antar Variabel}

Hasil penelitian menunjukkan hubungan antar variabel sebagai berikut.

Prestasi akademik merupakan hal yang sangat penting dalam menentukan keefektifan sekolah, sebagaimana dinyatakan oleh Beck dan Murphy (1996), Finn (1994), Prasch (1994), Sidi (2001). Jika keefektifan sekolah direpresentasikan oleh prestasi akademik, maka secara langsung variabel yang paling besar pengaruhnya 
terhadap prestasi akademik ialah kesehatan sekolah yaitu $43,56 \%$, disusul sumber daya manusia 20,25\%, sarana-prasarana $17,64 \%$, dan yang paling kecil pengaruhnya adalah peran serta masyarakat $12,25 \%$. Variabel pengukuran yang memberikan sumbangan terbesar untuk variabel kesehatan sekolah ialah mutu produk, disusul mutu proses, organisasi tepat, dan yang paling kecil adalah pemimpin memadai. Berdasarkan hasil penelitian ini, dapat dinyatakan bahwa untuk meningkatkan prestasi akademik melalui kesehatan sekolah, maka indikator penyumbang terbesar kesehatan sekolah harus ditingkatkan.

Sementara itu, sumber daya manusia adalah variabel yang memiliki pengaruh paling besar terhadap kesehatan sekolah. Diketahui bahwa $10,24 \%$ perubahan yang terjadi pada kesehatan sekolah secara langsung disebabkan adanya perubahan pada sumber daya manusia, 2,56\% adanya perubahan sarana-prasarana, dan 1,00\% adanya perubahan peran serta masyarakat. Jadi $13,80 \%$ perubahan yang terjadi pada kesehatan sekolah disebabkan oleh adanya perubahan tidak langsung sumber daya manusia yang ditunjang oleh sarana-prasarana, dan peran serta masyarakat. Dengan kalimat lain dapat dinyatakan bahwa variabel sumber daya manusia akan memiliki pengaruh lebih besar terhadap prestasi akademik apabila ditunjang oleh variabel kesehatan sekolah.

Besar pengaruh kesehatan sekolah terhadap prestasi akademik adalah sebesar $(0,66)^{2}$, yakni 0,4356 . Dengan demikian, dapat diketahui bahwa $43,56 \%$ perubahan yang terjadi pada prestasi akademik adalah disebabkan oleh adanya perubahan pada kesehatan sekolah. Kesimpulan hubungan antar variabel ialah: a) sumber daya manusia, sarana-prasarana, dan peran serta masyarakat berpengaruh terhadap kesehatan sekolah; b) sumber daya manusia, saranaprasarana, peran serta masyarakat berpengaruh terhadap prestasi akademik, dan c) dan kesehatan sekolah berpengaruh terhadap prestasi akademik.

Berdasarkan besaran persentase pengaruh variabel eksogen terhadap variabel endogen tersebut tampak bahwa variabel kesehatan sekolah berpengaruh paling besar terhadap prestasi akademik yaitu 43,56\%, sementara variabel sumber daya manusia memiliki pengaruh cukup besar terhadap prestasi akademik $(20,25 \%)$, namun demikian besarnya pengaruh variabel sumber daya manusia akan semakin meningkat apabila ditopang oleh variabel kesehatan sekolah, dalam hal ini diperoleh persentase pengaruh total (total effect) sebesar $(0,51)^{2}=26,01 \%$. Dengan demikian dapat dinyatakan dengan kalimat lain bahwa variabel sumber daya manusia akan memiliki pengaruh lebih besar terhadap prestasi akademik apabila ditunjang oleh variabel kesehatan sekolah. Sementara itu diketahui bahwa variabel sumber daya manusia yang memiliki pengaruh besar terhadap prestasi akademik tersebut dibentuk oleh tiga observed variables (indikator), yakni a) kualitas dan kemampuan dalam proses belajarmengajar dan evaluasi, b) penguasaaan dan pengembangan keilmuan, dan c) kemampuan untuk mengkomunikasikan masalah akademik.

\section{Simpulan dan Saran Simpulan}

Mengacu pada hasil penelitian, maka simpulan deskriptif persepsi guru terhadap variabel: a) kesehatan sekolah rata-rata baik; b) umberdaya manusia rata-rata kurang; c) sarana-prasarana rata-rata sedang; d) prestasi akademik rata-rata baik; e) peranserta masyarakat rata-rata cukup. Dalam hal prestasi akademik pada tahun 2010, rata-rata nilai UN SMP Negeri Standar Nasional termasuk dalam kategori baik, sementara SMP Negeri Non Standar Nasional dalam kategori cukup. Selanjutnya pengaruh antar variabel menujukkan bahwa berdasarkan hasil pengolahan data statistik dengan program Lisrel sebagai berikut: a) sumber daya manusia, saranaprasarana, dan peran serta masyarakat berpengaruh terhadap kesehatan sekolah; b) kesehatan sekolah berpengaruh terhadap prestasi akademik; dan c) sumber daya manusia, sarana-prasarana, peran serta masyarakat dan kesehatan sekolah berpengaruh terhadap prestasi akademik.

Hasil analisis uji hipotesis secara keseluruhan disimpulkan sebagai berikut: a) pengaruh sumber daya manusia, sarana-prasarana, dan peran serta masyarakat terhadap kesehatan sekolah sebesar $13,80 \%$; b) pengaruh kesehatan sekolah 
terhadap prestasi akademik sebesar 43,56\%; c) pengaruh sumber daya manusia, sarana-prasarana, peran serta masyarakat, dan kesehatan sekolah secara bersama-sama terhadap prestasi akademik sebesar $20,25 \%+17,64 \%+12,25 \%$ $+43,25 \%=93,70 \%$.

\section{Saran}

\section{Terhadap Manajemen Sekolah}

Berdasarkan hasil penelitian ini, disarankan dua model untuk meningkatkan keefektifan sekolah. Model pertama meningkatkan kesehatan sekolah dan prestasi akademik terutama melalui peningkatan pencapaian skor indikatornya yang memberi sumbangan terbesar, yaitu pemimpin memadai, dan organisasi tepat, serta persentase lulusan. Model kedua meningkatkan kesehatan sekolah dan prestasi akademik secara simultan dengan cara meningkatkan variabel yang paling besar pengaruhnya terhadap prestasi akademik, yakni sumber daya manusia.

\section{Terhadap Peneliti}

Disarankan untuk dilakukan penelitian, dengan melibatkan pihak-pihak yang lebih luas dan tidak hanya guru sebagai responden, tetapi juga melibatkan orang tua, komite sekolah, siswa, pejabat pemerintah di bidang pendidikan, dan sekolah lanjutan dengan jenjang lebih tinggi yang menerima lulusan SMP Standar Nasional Negeri (tracer study). Metode yang digunakan lebih baik jika ditambah dengan observasi lapangan dan dokumentasi sekolah. Dengan demikian kajian keefektifan sekolah memperoleh data dari berbagai pihak yang berkepentingan sehingga kajiannya lebih komprehensif. Namun agar penelitian terfokus dan lebih mendalam, disarankan satu judul penelitian hanya mengkaji salah satu aspek saja, misalnya kualitas sumber daya manusia (guru) saja atau sumber dana, sarana-prasarana saja untuk mengungkap indikator-indikator yang menyertainya.

\section{Pustaka Acuan}

Beck, L.G dan J. Murphy. 1996. The Four Imperative of a Successful School. London. Sage Publication Ltd

Creech, B. 1996. The Five Pillars of TQM terjemahan. Jakarta Binarupa Akasara

Dharma, Surya 2005. School Effetiveness and AcademicAchievements, An Empirical Evidence From American Public Schools. Salatiga. Wineka Media

Departemen Pendidikan dan Kebudayaan. 1998. Panduan Manajemen Sekolah. Direktorat Pendidikan Menengah Umum, Jakarta

Etzioni, Amitai. 1964. Modern Organizational New Jerse. Printice-Hall.

Finn, C.E. 1984. Toward Strategic Independence: nine commanddments for Enchancing School Effectiveness. Phi Delta Kappan April. 518-4

Garvin Missouri dan Gibbon 1986. Effective Schools Research and The Role of Professional. Diakses 1209-2006

Komariah A. dan C. Triatna. 2006. Visionary Leadership Menuju Sekolah Efektif. Jakarta Bumi Aksara

Laughlin. T. M., 2006: Effective Schools Research and The Role of Professional Learning Communities. Asssistant Superintedent, Student Services San Bernardino County Superintendent of School http://www.fcoe.k12.ca.us/eduscrvc/spec_ed_docs\%5C Effective\%20Schools\%20 10-04.ppt diakses 04-02-2008

Maquardt M. dan A. Reynold. 1994: The Global Learning Organization. New York. Irvins Professional Publishing

Mohrman, S.S. P. Wohlstetter. Smayer. 1994. School Based Management: Organizing for High Performance, San Francisco: Jossey-Bas Publisher

Mortimore, P. 1993. School Effectiveness and The Management of Effective Learning and Teaching. School Effective and School Improvement. Vol 4,

Nugroho. 2007. Rencana Pengembangan Sekolah. Naskah disampaikan dalam Forum Manajerial Kepala sekolah SDLB/SLB Jateng. Tanggal 9-11 Juli 2007 
Owens. Robert G. 1995. Organizational Behavior in School Fifth Edition, Boston. Allyn and Bacon Peter Sange. 1990. The leader's New York: Building, Learning Organizations. Sloan Management Review. 32. No 1. New York. Irvin Professional Publishing.

Prasch. J.C. 1984. Reserving The Trend Towards Centralization. Educational Leadership. 42(2)

Psacharoupoulos. 1987.Economics of Education Research and Studies. Oxford dan New York. Pergamon Press

Republik Indonesia. 2005. Peraturan Pemerintah Nomor 19 Tahun 2005 tentang Standar Nasional Pendidikan. Jakarta 2005

Sallis, E. 2006. Total Quality Management in Education, Alih Bahahasa Ahmad Ali Riyadi dkk. Yogyakarta. IRCiSoD.

Sidi, Indra Jati. 2001. Menuju Masyarakat Belajar: Menggagas Paradigma Baru Pendidikan. Jakarta: Paramadina dan PT Logos Wacana IImu

Soegito, AT. 2006: Total Quality Manajement (TQM) dan Kepemimpinan Transformasional untuk Pendidikan Berkualitas. Pidato Pengukuhan Guru Besar UNNES. Sabtu 10 Juni 2006

Standfield. 1987. Characteristics of Effective Schools. CT Council of P\&C Assosiations. http:// www.schoolparents.canberra.netau/effective_schools. Diakses 12-09-2006

Sugiyono. 2000: Metode Penelitian Administrasi. Bandung. Alfabeta CV

Supriadi, R. 2005. Analisis Sarana dan Prasarana Pendidikan SD/MI, SMP/MTs, dan SMA/MA/SMK. Seminar Nasional Pendidikan. Semarang. 04 Mei 2005

Suyanto. 2002. Implikasi Kurikulum Tahun 2001 Pada Pendidikan Dasar dan Menengah. Seminar Nasional Pendidikan PPS Unnes 27 Februari 2002

Zamroni. 2000. Paradigma Pendidikan Masa Depan. Yogyakarta. Bigraf Publishing. 